\title{
Education in the Internet Age
}

\author{
Natalia L. Selivanova ${ }^{1}$, and Irina A. Tagunova ${ }^{2, *}$ \\ ${ }^{1}$ ISED RAE, Center of Strategy and Theory of Personality Upbringing, 105062, Moscow, Russia \\ 2 ISED RAE, Comparative Education Center, 105062, Moscow, Russia
}

\begin{abstract}
This article describes the development of national education systems in the context of the Internet. The author analyzes the traditions that are disappearing in the era of network development and summarizes the innovations, which replaced the tradition in education. The article also deals with the modern education trends in the Internet era. All the author's attention is focused on how these transformations in education are reflected in the fate of the students. The article describes the experience of almost all continents.
\end{abstract}

According to the theory of N.D. Kondratieff, the acceleration of the technological progress shows that the mankind will enter soon into a phase of the sixth technological order, hints of which are already visible in the developed world. The sixth order is aimed at the use of high technologies, namely nanotechnology, genetic engineering, micromechanics, fusion energy, etc. It is expected that there will be an artificial intelligence and quantum computer as a result of the above-mentioned areas of knowledge. They will allow humanity to reach an entirely new community management system and economy. These major changes are the main challenges to which the education system should be ready.

Today the world lives in the fifth technological order. This way of life is based on achievements in the field of computer science, microelectronics, biotechnology, genetic engineering, development of satellite communication, space, use of new materials and energy. In the context of the fifth order we can see the transition of the society to a unified network of agencies and companies connected to the Internet, carrying out cooperation in all fields of economy, culture and other spheres.

How is a new type of interaction reflected in modern society and education?

The Great Thinkers argue that education is not a category of knowledge, but a life one [1]. A. Gromyko, like many other scientists, believes that: "The Internet is the quintessence of the postmodern system and lifestyle, this is a space where postmodernism is deployed and forms the most adequate meaning: entering the Internet, everyone immerses in the essence of the post-modern era in all its philosophical and ideological and anthropological specificity" [2]. In such circumstances J.-F. Lyotard says: "Knowledge is produced and will be produced in order to be sold; it is consumed and will be consumed to obtain the value of the new product, and in both cases, to be exchanged" [3]. In such circumstances, according to A. Toffler, knowledge is increasingly replaced by the information: "... we have more stuff with modular short bursts of information - advertising, instructions, theories, fragments of news, some truncated cut pieces do not fit into our old mental cell" [4]. S. Gary and B. Riga wrote that "today we are witnessing a real evolutionary leap. In this new situation, they say, it is important the humanity will not become an appendage of the computer [5]. N. Carr has the same point of view. It shows how the new "mind tools" for human life (the alphabet, the printing press, the computer) alter neural connections of the brain routes. N. Carr shows how our brain is influenced by the experience and technology that humanity uses to search, store and share information. He shows it on the basis of the results of recent research in neuroscience. N. Carr shows how the Internet reshapes mankind in his own image and likeness [6]. E. Blair also says that the excess of information introduced by the Internet should be considered as a serious problem and that in these new conditions it is necessary to seek forms that allow a person does not become entangled in the networks in the search for true knowledge [7]. E. Pariser says on this subject. He believes that the Internet restrict our information. His opinion is based on the fact that Internet companies use multiple algorithms and filters to represent $u$ in the form of information that is most relevant. Accordingly, he said, we cannot see a coherent picture through these filters, moreover, we do not notice these filter and believe that the information we have received is sufficient to form a true knowledge [8]. K. Shirky predicts serious changes that will occur when digital technology penetrate deeper into our lives. He claims that the technology release a lot of time for humans, that creates a "cognitive surplus". In the situation of the released time, a person should know how to use this cognitive surplus to the best advantage, for example, to combine efforts in order to create global projects. [9] The relationship of such concepts as

Corresponding author: tagunovair@mail.ru

(C) The Authors, published by EDP Sciences. This is an open access article distributed under the terms of the Creative Commons Attribution License 4.0 (http://creativecommons.org/licenses/by/4.0/). 
thinking, information and knowledge B.B. Slavin analyses in his books [10, 11].

The strong tradition in education was questioned in the Internet era. In particular, the universities lose their classic role in new conditions of global education development. Their financial support is disproportionately growing and becoming unsustainable both for universities and for students. We can also see the changes related to teaching methods, for example, to such method as a lesson that was developed long before there was printing. The medieval method looks absurd in the age of computers. But the awareness of the need for change in education is extremely slow. While in other areas of technology the society has revolutionized, the education is still in a position of seriously lagging element of the social development due to the fact of its long adaptation cycles laid to the new conditions and there is no understanding of the realities of the market.

At the same time, the need to live in a new environment promotes partial solution of the urgent education problems today. For example, governments of nation-states begin to create an open licensed professional and vocational training content. In particular, on-line tutorials allow, firstly, spend less on paper edition textbooks, and secondly, to invest in a continuous update of the content. Open educational resources allow us to offer students the content of the training material developed by highly professional teachers. For this purpose, thousands of educational videos are created, everyone can use them. The Wikipedia and other reference sources provide an open access to the information. Of course they need to be improved, so that they can be fully trusted. The British Museum Library opened "Living Words" website specifically for schools. This website provides teachers and students with their archives with the help of a number of projects involving the active use of the reference material. Much attention is now paid to the formation of such training of teachers, which would correspond to the realities of a new time - a course of various forms of multimedia study. So, thanks to the European project "Extranet for teachers" a database was created. It aimed at teachers training and to integrate media into their daily teaching activities. In addition, a tendency to discuss educational issues at the international level by means of television, video conferencing, and chat actively develops in today's educators' environment. In different countries sites have already been formed and filled with rich information to help teachers, students and parents in their studies. France developed "Thot" network, which houses a collection of numerous francophone educational materials on any academic subject. This site is intended for teachers from France, Canada and other Frenchspeaking regions. The Flemish Department of Education in Belgium opened up a database of all academic disciplines specifically for middle school students in the Internet. There is a site for information exchange in the field of education in Norway. Norwegian school exchanges experience and solutions of pedagogical problems using this national website. In Italy, a special section devoted to education is submitted to the Senate
Web site. The German Institute for International Educational Research publishes a calendar of conferences and education technology events open for additions and changes in Internet. The European educational school network servers the news from the network of European schools. This server publishes weblogs of the European teachers and "World of Children" journal in five languages. An infinite number of websites dedicated to the formation are located in the United States. In Latin America, an extensive information network to help universities (MexNet) is created. It actively develops in Mexico, Venezuela, Argentina, Brazil and other countries. In Russia, many educational sites are opened to support administration, teachers and students. In particular, there are the "Russian Education" Federal portal (edu.ru), the "Russian educational portal (school.edu.ru) and others. The upcoming technologies can greatly facilitate the learning process. For this purpose, there are special agencies that develop individualized learning programs for students. Among them, for example, the resources such as: https://www.knewton.com, http://ww2.kqed.org. They go into space online and offer their services widely. In Russia - there is, for example, the portal of information support of the Unified State Exam (age.ru). At the same time different types of gamification are developed in the world, they help to motivate students to learn. Universities, seeing the risks and high costs of traditional training, are gradually moving to a full line training for all of their students. For example, in the US the Massachusetts Institute of Technology has laid out the site, which presents the entire content of the student training in this university. There are a lot of other universities sites, such as site MERLOT (https://www.merlot.org), whose members are US colleges, individual faculties and even the entire universities, for example, the California State University, the University of Michigan's system and the University of Central Oklahoma. This site offers to work with them in several languages. Such leading US universities like Stanford, Princeton and Harvard offer their best professors to lecture with virtual ones. The teachers of colleges and universities in different countries begin using this format. For example, instead of a lecture at a college or university in any country a lecturer encourages his students to turn on the computer and listen to the video course, which his colleague from Stanford University does. In Canada, there are universities that are engaged only in distance education, such as Tele-University of Quebec.

A lot of on-line colleges are also recorded in China. The South Korea is famous for her online forms. The growing interest to on-line training forms is demonstrated in the Middle East and Africa. The South Africa students use smartphones in learning. The same trend we can see in schools. In particular, "A community of teaching and studying" has developed a website for the American high school teachers (www.curriki.org), where they can not only get information on all subjects, but also offer their own experience. Entire districts in the US offer their open educational resources to all schools. In particular, there is a CK12 
(http://ww2.kqed.org/mindshift/2011/01/03/the-livingbook-movement-free-education-for-all/), which is a part of an open textbook initiative in California. This site plays a major role in students solving the problem of choosing a future profession. Internet like no other training method allows for the formation of the idea of learner-centered education. This idea was developed and implemented on http://www.edutopia.org site. There are many schools that implement this idea on the basis of a method of projects (http://www.edutopia.org/stw-mainepbl). The concept of "standardized" education can leave in the past because of the increasing trend towards individualization requests for specific education, said $\mathrm{M}$. Maklyuin [13]. This is due to the fact that the education received by the students in terms of self-selection ceases to be a standard-deterministic. In such conditions of having education, a student becomes the subject of designing his/her own education. At the same time education is also sharpened to a specific student. It becomes a moving and ever-changing. Today, the main criterion for the popularity of certain educational services is their ability to meet the diverse needs of users.

In the twenty-first century, everyone understands that a graduate leaving school must be prepared to live in society without borders. Such personality traits as an ability to cooperate, openness to innovation, critical thinking and the ability to communicate, become necessary for everyone. Such training is almost not possible where dominates the practice of teacher students. In order to obtain the above-mentioned skills, students go online and get the knowledge there independently, adaptive to the new way of learning. Of course, there are some risks, when a student got knowledge in such a way, because we cannot be always sure that we always have a reliable information on the Internet. But many specialists work a lot to make information reliable, in particular, on such website as "Napa New Technology". Today we know that online students do not only acquire new knowledge, using Internet, but are also formed as individuals. As a teacher is no longer the chief mentor, the value orientation of students is also developed through Internet. Accordingly, it exacerbates the problem of social identity, often breaking the boundaries of identity. Internet brings significant changes in the outlook of the student and his/her way of perceiving the world. M. Castells believes that over time, each member of the global network society will be transformed into one network, receiving almost full autonomy [12].

The following changes in the education traditions should be seen as the main trends of modern education in the era of the Internet.

In relation to the students: the students today actively participate in the transformation of the learning process; students are considered as individuals with different needs, learning styles and intelligences. Students are now seen as creators, not consumers. This shift in attitude towards students was implemented in a large number of products produced by them: video, projects, etc. Much attention in the classroom or auditorium is now paid to the presentation of educational material in innovative ways, suggesting not only the study of educational material, but the use of them, as in the walls of the institution and outside it. More willing teachers use learning tablets and smartphones in order to link the learning to real life. There is more and more evidence that an experience and active learning are effective learning strategies in the context of the new challenges of the $21^{\text {st }}$ century.

With respect to the teacher: teachers today, in some sense are marginalized, at least in regard to the learning content in the form of a lesson or lecture. The role of the teacher has changed dramatically. Most students work on-line. Today, on-line training is highly appreciated; it is actively supported by the business. View videos, collaboration with classmates, active involvement in educational activities allow a student to reach the objectives of the course without any help of a teacher. Meanwhile, a modern teacher can be very helpful, when offers methods to facilitate penetration into the education problem to students, or alignments operation with educational and methodological continuum, etc.

In the field of evaluation: in the field of education there is a steadily growing interest in the use of new sources of knowledge to personalize the experience of the student in order to continuously formative assessment of his/her level and learning style, as well as evaluate the effectiveness of its achievements. This interest stimulates the development of a relatively new trend in teaching - data-driven learning and assessment. The main element of this trend is the analytics training and the use of web analytics of that area of knowledge, which is used in enterprises for the analysis of commercial activity. This study contributes to the students, teachers and researchers understanding of the degree of progress of students, their level of interaction with the online text and learning environment, the degree of mastery of the courses used in the learning process. Meanwhile, not all countries consider this method as a legitimate approach to education; in particular, in Germany people believe that it is impermissible peeping into the private lives of learners.

In the educational environment: in secondary education. There is a revision of the traditional paradigm of training and education in the secondary education. The schools increasingly use design methods and other similar methods of learning, based on challenges. All of these methods necessarily involve changing learning activities and remove the time limit on the lesson. They also require much classroom space. Accordingly, the planning of this method of learning involves different curriculum. Today it is more and more recognized that the credit hour, or the lesson time is not adequate to new approaches to learning. In higher education: there is an entrepreneurship in the learning process. There are a growing number of start-ups in the universities. Students are introduced to the design thinking and prototyping in the practical training courses. Then entrepreneurial centers offer students and graduates a lot of different programs. Student startups are increasingly seen as a way of bringing innovation to the campus. The results are considered as start-ups creating something much more useful than just scribbled them on pieces of paper 
exams. In particular, the development of mobile and web applications, made by the students in the New York University, can compete with the technology solutions in companies. Such entrepreneurial laboratories have a place at other universities also (http://horizon.wiki.nmc.org/Trends).

In the sphere of interaction: the collective efforts of schools and districts become important for the future of higher education. More and more educational institutions are included in consortia, combining two or more institutions, pool their resources or join strategic innovation in education. Today, the global environment allows universities to combine, bypassing the international border, and work on common tasks and use common technology to conduct general research and practice common values. Technologies have increased tendency to form open communities and university consortia. Teachers and administrators recognize the usefulness of such collective efforts and consider them as a support in the process of institution modernization, in particular, its technological infrastructure and IT services. Educational institutions are united not only within the boundaries of a single state, but also outside its borders, as has been said above. In particular, the European Union has allowed students to navigate through different training programs in various countries. Students around the world migrate in search of better conditions of education, better training programs. American universities, open the branches in other countries, including in Asia. At the international level, the project is now entered "Global Education". It is positioned as a model of education in the world. The main idea of the project: education is the sphere of business, it must be continuous and its competence, knowledge and skills must be constantly updated. Many universities in the world tend to get in the "Global Education"; Russian universities are also involved in this project. Under this project, universities should seriously change, in particular, all their courses must comply with international quality standards; universities need to work together with domestic and foreign teachers, they need to be international, and one-third of their programs should be carried out in English.

In the educational Internet space: there is a wide dissemination of open educational resources. These resources are designed to help teachers, students and researchers in the field of education. They are in the public domain or released with a license of intellectual property that allows to freely use them at any convenient time for the user.

In the educational environment: there is a revision of classrooms. New forms of learning and training require new spaces for these purposes. Many schools and universities begin to rebuild the learning environment in order to organize a more active learning. Space in schools and universities are increasingly designed to facilitate interaction between the students, when they are enrolled in training on the basis of projects. These spaces are formed in order to organize the mobility of students, flexibility of the educational process and for the use of wireless bandwidth. "Smart rooms" are designed in order to have web conferencing and other remote activities.
Large displays and screens are placed in classrooms in order students can have their studies in a group that implement digital projects and have presentations. In higher education in the process of escaping from the traditional lecture to more practical scenarios, university audiences resemble real conditions at work or in other places that promote interaction, as well as for crosscutting issues.

The use of computers in education: numerous studies have shown that children's writing skills increase significantly when they use the computer as a writing instrument. This is partly because students are exempt from the restrictions which are needed in forming letters by hand skill, and also because they grasp the idea easier, using a word processor [14]. In schools computers realize the dream of individualized learning, collaborative learning and facilitate intercultural communication. Modern computers allow students with disabilities to actively join in the process of education [14]. Technology facilitates the access to information; the speed of receiving it depends on how close the computer is located. Technology makes learning fun and easy. Today, this fact is of great importance, because the quality of education, particularly in higher education is evaluated in terms of students' satisfaction with the learning process. The use of computers in adult learning helps companies to remain competitive, and adults do not lose their jobs. The company's learning management system is a key element of effective professional development. That's why E-learning market shows a fast and significant growth in the world [15]. Markets of different regions of the world differ from each other. The most mature markets are the markets of the USA and Western Europe. US E-learning is aimed at independent learning of students, when they can use their own individual style and pace of learning. US produce more of these programs; Western Europe and Asia buy them. Cloud also changes methods of employees training. Elearning and its software also played an important role in training [15]. The future of such education is a synthesis of science and art education training.

In the world: the unification of education is at the international level. Thanks to the development of the Internet there is the unification of education on a global scale. Not only education standards, but the entire educational management now has the cooperative nature. The most pronounced examples of the co-operative nature of education, developing the Internet, are particularly oriented reforms of national education systems, typical patterns of education, the transformation of forms of education in international ones. In addition, in secondary and higher education, educational institutions, which cannot be now attributed to the concept of a "national institution", actively function. These schools worldwide offer standardized educational content within the universal forms of education. These are, in particular, MBA schools, corporate universities, language schools and different famous authors' schools. Even today, it is appropriate to say that the global nature of the Internet contributes to the formation of the education output of the closed space systems. There is a 
close cooperation between various national paradigms of education, forms of education organization.

The above data give grounds to assert that in the conditions of Internet development the education is gradually losing its traditional features, and increasingly adapting their systems to the challenges of today. In the new technological and social conditions of society the development of education processes actually go beyond the boundaries of nation-states, regional alliances and blocs. There is a unification of education in a global dimension, turning it into a network and variety of educational services. Online education has long been a great melting pot of education content and values, because of the variety of educational cultures vary the mechanisms for on-line training.

\section{References}

1. M. Scheler, Selected Philosophical Essays, (Northwestern University Press, Evanston, 1973)

2. N.V. Gromyko, Centaur, 55, 27 (2001) [In Rus]

3. J.F. Lyotard, The Postmodern condition (Aletheia, St. Petersburg, 1998)

4. A. Toffler, Future Shock (OOO "Izdatelstvo AST", Moscow, 2001)

5. S.V. Gary, Mega Brain online. The man in the Internet era (Azbuka-Atticus, Hummingbird Series GALILEO, Moscow, 2011)

6. N. Carr, The Shallows: What the Internet is doing to our brains, (BestBusinessBooks, Moscow, 2012)
7. A. Blair, Too Much to Know: Managing Scholarly Information before the Modern Age (Yale University Press, Yale, 2010)

8. E. Pariser, Filters For wall: What the Internet is hiding from you (Alpina Business Books, Moscow, 2012)

9. K. Shirky, Including the brain: free time in the Internet era (Career Press, Moscow, 2012)

10. B.B. Slavin, Collective Intelligence Epoch: On the role of information in society, and about the nature of human communication (Stereotype, Moscow, 2013)

11. B.B. Slavin, Birth Collective Intelligence: About the new laws the network society and a network economy and their impact on human behavior: The Great Transformation of the third millennium (Stereotype, Moscow, 2014)

12. M. Castells, Galactica Online (U-factor (with the assistance of the Humanitarian University Press), Ekaterinburg, 2004) [In Rus]

13. M. McLuhan, Understanding Media: External Expansion man (Hyperborea, Moscow, 2007) [In Rus]

14: B.J. Poole, Teaching in the Computerized Classroom, 7, 308, 311 (2009) [In Rus]

15. E-learning market-trends and forecast, 2014-2016 (Docebo-report, Moscow, 2016)

16. R. Wergerif, Dialogic: Education for the Internet Age (Routledge, London, 2013)

17. S.V. Ivanova, Education in organizational and humanistic dimension (Russian University of Peoples' Friendship, Moscow, 2007) [In Rus] 